\title{
SKUTKI PRAWNE PRZYJĘCIA \\ I OPUBLIKOWANIA KONKLUZJI \\ DOTYCZĄCYCH NAJLEPSZYCH DOSTĘPNYCH TECHNIK \\ NA PRZYKŁADZIE REGULACJI DLA DUŻYCH OBIEKTÓW ENERGETYCZNEGO SPALANIA
}

\section{WPROWADZENIE}

Pojęcia „dostępne techniki” oraz „najlepsze dostępne techniki” zostały wyjaśniony zarówno przez przedstawicieli doktryny prawa ochrony środowiska ${ }^{1}$, jak i przez prawodawcę na szczeblu unijnym i krajowym. W doktrynie przyjmuje się, że przez „dostępne techniki” należy rozumieć techniki „o takim stopniu rozwoju, który umożliwia ich praktyczne zastosowanie w danej dziedzinie przemysłu, z uwzględnieniem: warunków ekonomicznych i technicznych oraz kosztów inwestycyjnych i korzyści dla środowiska, które prowadzący działalność może uzyskać”. Z k kolei pojęcie najlepszych dostępnych technik oznacza najbardziej efektywną technikę w osiagnnięciu wysokiego ogólnego poziomu ochrony środowiska jako całości”' Prawodawca unijny wyjaśnił zaś pojęcia „dostępne techniki” oraz „najlepsze dostępne techniki” w treści art. 3 pkt 10 dyrektywy Parlamentu Europejskiego i Rady 2010/75/UE z 24 listopada 2010 r. w sprawie emisji przemysłowych (zintegrowane zapobieganie zanieczyszczeniom i ich kontrola) ${ }^{4}$. Podobne sformułowania tych pojęć zawarł prawodawca krajowy w art. 3 pkt 10 ustawy z 27 kwietnia 2001 r. - Prawo ochrony środowiska ${ }^{5}$. Najlepsze dostępne techniki $\left(\mathrm{NDT}^{6}\right)$ traktowane są przez

\footnotetext{
${ }^{1}$ Szerzej Ciechanowicz-McLean (2015): 110-111; Kenowska (2009): 136; Erechemla (2010): $40-41$.

2 Jendrośka, Bar, Górski (2005): 49.

3 Jendrośka, Bar, Górski (2005): 49.

${ }^{4}$ Dz. Urz. UE L 334/17 z 17.12.2010 r. (dalej jako: dyrektywa 2010/75/UE). Szerzej na temat tej dyrektywy: Bar (2012): 38; Langlet, Mahmoudi (2016): 200-201.

${ }^{5}$ T.jedn.: Dz. U. 2018, poz. 799 ze zm. (dalej p.o.ś.). Szerzej: Korzeniowski (2010): 346-347.

${ }^{6} \mathrm{~W}$ polskim oficjalnym tłumaczeniu unijnych aktów istotnych dla problematyki artykułu oraz w ustawie je wdrą̇ającej użyty został skrót angielskojęzyczny „BAT”, natomiast angielskojęzyczne rozwinięcie tego skrótu termin Best Available Technics jest tłumaczony w tych aktach prawa na język polski jako: „najlepsze dostępne techniki (BAT)”. Autorka uznaje zabieg częściowego tłumaczenia za błąd translatorski. Tym bardziej że w większości państw członkowskich tłumaczeniu podlega również skrót. W francuskojęzycznej wersji dyrektywy 2010/75/UE oraz de-
} 
przedstawicieli doktryny jako jedna z zasad prawa ochrony środowiska ${ }^{7}$ oraz $\mathrm{w}$ połączeniu z pozwoleniem zintegrowanym jako instrument zintegrowanej ochrony środowiska w działalności przemysłowej ${ }^{8}$.

Konkluzje dotyczące NDT zostały z kolei wyjaśnione w art. 3 ust. 12 dyrektywy 2010/75/UE, w myśl którego jest to dokument zawierający elementy dokumentu referencyjnego NDT, który formułuje wnioski dotyczące najlepszych dostępnych technik, ich opisu, informacji służącej ocenie ich przydatności, poziomów emisji powiązanych z najlepszymi dostępnymi technikami, powiązanego monitoringu, powiązanych poziomów zużycia oraz, w stosownych przypadkach, odpowiednich środków remediacji terenu. Powyższa definicja została transponowana do polskiego prawa krajowego na mocy ustawy z 11 lipca 2014 r. zmieniającej p.o.s. ${ }^{9}$ przez dodanie do art. 3 tej ustawy pkt 8d. W celu określenia NDT oraz ograniczenia występujących w Unii różnic w zakresie poziomów emisji z działalności przemysłowej, postanowienia dyrektywy 2010/75/UE wprowadziły też obowiązek sporządzania dokumentów referencyjnych NDT (a także cyklicznego dokonywania ich przeglądu i aktualizacji), a najważniejsze elementy dokumentów referencyjnych NDT nazywane konkluzjami dotyczacymi NDT przyjmowane mają być w drodze procedury komitetowej (motyw 13 dyrektywy 2010/75/UE). Konkluzje maja zatem charakter następczy w stosunku do dokumentów referencyjnych NDT, są sporządzane na ich podstawie. W literaturze przedmiotu zwraca się uwagę na złożoność procedury uzgadniania treści dokumentów referencyjnych NDT i przyjmowania konkluzji dotyczących NDT (kwestie techniczne i technologiczne oraz ekonomiczne, ale też społeczne i polityczne). Wysuwane są nawet poglądy, że proces podejmowania decyzji ma często bardziej polityczny niż technologiczny wymiar, ochrona środowiska zostaje często wyparta przez interesy sektora przemysłu państwa członkowskiego ${ }^{10}$. Zgodnie z art. 14 ust. 3 dyrektywy 2010/75/UE konkluzje dotyczące NDT stanowią natomiast odniesienie przy określaniu warunków pozwolenia zintegrowanego. Na ich podstawie w treści tego pozwolenia powinny zostać określone wielkości emisji dopuszczalnych dla danej instalacji w normalnych warunkach eksploatacji oraz wymogi dotyczace monitorowania (art. 15 ust. 3 i art. 16 ust. 1 dyrektywy 2010/75/UE).

Konkluzje dotyczące NDT dla określonych rodzajów instalacji przemysłowych sa wypracowywane w trybie art. 13 dyrektywy 2010/75/UE, przyjmowane zgodnie z procedura komitetowa, a następnie publikowane $\mathrm{w}$ formie decyzji wykonawczej: 31 lipca 2017 r. (po kilku latach prac) przyjęta została decyzja wykonawcza Komisji 2017/1442 ustanawiająca konkluzje dotyczące najlepszych dostępnych technik (NDT) w odniesieniu do dużych obiektów energetycznego spalania zgodnie z dyrektywą 2010/75/UE, która 17 sierpnia została

cyzji wykonawczej Komisji (UE) 2017/1442 używa się wyłącznie francuskojęzycznej terminologii: meilleures techniques disponibles, MTD; podobnie w niemieckojęzycznej wersji językowej wymienionych aktów: besten verfügbaren Techniken, BVT.

${ }^{7}$ Górski (2018): 282-283.

8 Ciechanowicz-McLean, Nyka (2011): 189.

${ }^{9}$ Dz. U. 2014, poz. 1101.

${ }^{10}$ Lange (2008): 104-110. 
opublikowana ${ }^{11}$. Konkluzje dotyczące NDT dla obiektów energetycznych maja zastosowanie do instalacji energetycznego spalania paliw o co najmniej $50 \mathrm{MW}$ całkowitej mocy dostarczanej w paliwie, ale także do bezpośrednio związanych z nimi niektórych instalacji zgazowania węgla lub innych paliw (o całkowitej nominalnej mocy dostarczonej w paliwie wynoszacej co najmniej $20 \mathrm{MW}$ ) oraz spalarni i współspalarni odpadów (o określonej wydajności). Przy czym spod tak ustalonego zakresu przedmiotowego zostały wyłączone niektóre instalacje spalania (np. instalacje korzystające $\mathrm{z}$ derogacji przyznanych na podstawie art. 33 i 35 dyrektywy 2010/75/UE w okresie ich trwania).

Przyjęcie, a przede wszystkim opublikowanie konkluzji dotyczących NDT dla obiektów energetycznych skutkuje zmianą części wymagań środowiskowoprawnych funkcjonowania instalacji objętych tymi konkluzjami, a w konsekwencji szeregiem obowiazków głównie formalnoprawnych, które musza zostać zrealizowane przez organy właściwe do wydawania pozwoleń zintegrowanych, a także czynności o charakterze formalnoprawnym oraz faktycznym, które zobowiązane sa podjąć i zakończyć (w okresie czterech lat od publikacji konkluzji, tj. do 17.08.2021) podmioty prowadzące określone instalacje. Jednak opublikowanie Konkluzji dotyczacych NDT dla obiektów energetycznych wywołało zainteresowanie tym zagadnieniem nie tylko wśród organów administracji i podmiotów prowadzących instalacje podlegające tym konkluzjom. Sektor energetyczny należy bowiem do obszarów strategicznych z punktu widzenia całej gospodarki i polityki państwa. Funkcjonowanie tego sektora ma wpływ na wiele innych dziedzin gospodarki i życia społecznego ${ }^{12}$.

Celem artykułu jest analiza skutków wynikajacych z przyjęcia, a przede wszystkim opublikowania (z tym momentem nabierają one mocy wiążącej) konkluzji dotyczące NDT dla obiektów energetycznych, tj. zmiany sytuacji środowiskowoprawnej funkcjonowania instalacji objętych tymi konkluzjami, a w konsekwencji obowiązków wynikających z tego faktu dla organów administracji oraz podmiotów prowadzących określone instalacje. Artykuł ten zmierza też do zarysowania następstw nieterminowej lub nienależytej realizacji tych obowiązków (zarówno dla państwa członkowskiego UE, jak i przedsiębiorcy prowadzacego instalację). W punkcie drugim artykułu przedstawiony został charakter prawny konkluzji dotyczących NDT, z czym wiąże się to, że są one zdolne wywierać określone skutki prawne, nakładać obowiazki na organy administracji i podmioty prowadzące określone instalacje. Skutkiem przyjęcia, a przede wszystkim opublikowania konkluzji dotyczących NDT dla obiektów energetycznych, analizowanym w punkcie trzecim tego artykułu, jest zmiana sytuacji środowiskowoprawnej funkcjonowania instalacji objętych tymi konkluzjami. Instalacje te nie podlegają już ogólnym (regulowanym w dyrektywie 2010/75/UE i przepisach krajowych ją implementujących) wymaganiom w zakresie poziomów dopuszczalnych emisji oraz zakresu i sposobu monitorowania

11 Dz. Urz. UE L 212/1 z 17 sierpnia 2017 r. (dalej jako: konkluzje dotyczące NDT dla obiektów energetycznych). Wniesienie przez Polskę do Trybunału skargi o stwierdzenie nieważności tej decyzji nie wstrzymuje jej wykonania. Odnośnie do skargi o stwierdzenie nieważności decyzji: Kowalik-Bańczyk (2012): 414-435.

12 Szerzej Sobieraj (2013): 257. 
ich wielkości, ale wymaganiom określonym w konkluzjach dotyczących NDT. Przy czym zakres oraz czas związania tymi wymaganiami jest zależny, odpowiednio od właściwej kwalifikacji instalacji lub możliwości skorzystania z określonych odstępstw. Przedmiotem punktu czwartego jest analiza obowiązów formalnoprawnych wynikających z opublikowania konkluzji dotyczących NDT dla obiektów energetycznych dla organów właściwych do wydania pozwoleń zintegrowanych (poszerzenie zakresu kontroli nad pozwoleniami zintegrowanymi) oraz dla przedsiębiorców prowadzących określone instancje. W punkcie piątym zostały przedstawione skutki, z jakimi powinien liczyć się prowadzący instalacje, jeżeli nie realizuje należycie i terminowo spoczywających na nim obowiązków formalnoprawnych (niezłożenie wniosku o zmianę pozwolenia zintegrowanego) i faktycznych (niedostosowanie instalacji do określonych wymagań) wynikających z opublikowania konkluzji dotyczących NDT.

\section{CHARAKTER PRAWNY KONKLUZJI}

Konkluzje dotyczace NDT od dnia ich ogłoszenia w dzienniku urzędowym UE mają charakter wiążący prawnie dla instalacji, których dotycza, działających na obszarze państw członkowskich UE. Nie istnieje wymóg implementacji decyzji w przedmiocie konkluzji dotyczących NDT (ze względu na jej charakter) do krajowych porządków prawnych. Jest ona bezpośrednio stosowana i bezpośrednio skuteczna. Bezpośrednie stosowanie aktu prawa unijnego oznacza, że dany akt automatycznie, z chwilą ogłoszenia, obowiazuje w krajowym porządku prawnym, staje się częścią systemów prawnych państw członkowskich ${ }^{13}$ i może być podstawą rozstrzygnięć krajowych organów (co do zasady jest stosowany na terytorium państw członkowskich bez podejmowania środków legislacyjnych lub regulacyjnych). Zgodnie natomiast z zasadą bezpośredniego skutku podmioty prywatne mogą powoływać się na prawa i obowiązki wynikajace $\mathrm{z}$ danego unijnego aktu prawnego ${ }^{14}$. Konkluzje dotyczące NDT sa zatem instrumentem ujednolicenia ${ }^{15}$ prawa ochrony środowiska ${ }^{16}$. Konkluzje są ważne do osiagnięcia zintegrowanego podejścia państw członkowskich do problemów zanieczyszczenia środowiska ${ }^{17}$. Dokumenty te bezpośrednio kształtują treść pozwolenia zintegrowanego i stanowia jeden z najskuteczniejszych instrumentów zintegrowanego zarządzanie środowiskiem ${ }^{18}$. Sa instrumentem osiagania celu ochrony środowiska i ochrony wartości, jaka jest środowisko w sektorze energetycznym ${ }^{19}$. Konkluzje dotyczące

\footnotetext{
${ }^{13}$ Szerzej Kalisz (2007): 73.

${ }^{14}$ Szerzej Hedemann-Robinson (2015): 265-270; Brzeziński (2010): 104-176.

15 Choć częstszą forma ,oddziaływania” na prawo krajowe przez unijnego prawodawcę w obszarze ochrony środowiska jest harmonizacja: Kenig-Witkowska (2011): 149-150.

${ }^{16}$ Lee (2012-2013): 371; Oosterhuis, Peeterson (2014): 97.

${ }^{17}$ Oosterhuis, Peeterson (2014): 98; Górski (2014a): 623.

18 Ciechanowicz-McLean (2015): 98-99.

19 Szerzej Szafrański (2014): 175-178; Muras, Swora (2016).
} 
NDT dla obiektów energetycznych nakładają zatem bezpośrednio na podmioty prowadzące określone instalacje obowiązek dostosowania, w ciagu czterech lat (od publikacji konkluzji) prowadzonych instalacji do wymagań ujętych w tych konkluzjach (obowiązki formalnoprawne oraz faktyczne), a na organy administracji publicznej obowiazki zmierzające do zapewnienia stosowania tych regulacji prawa unijnego. Obowiązki organów administracji możemy zakwalifikować do trzech grup. Po pierwsze, jest to co do zasady bezwzględny obowiązek takiego konstruowania pozwoleń zintegrowanych, aby ich treść czyniła zadość wymaganiom zawartym w konkluzjach dotyczacych NDT dla obiektów energetycznych, w szczególności w zakresie poziomu efektywności energetycznej, wielkości emisji do powietrza i wody oraz sposobu i zakresu ich monitorowania (a contrario bezwzględny zakaz wydawania pozwoleń zintegrowanych niezgodnych z treścią konkluzji). Po drugie, na organie administracji ciąży obowiązek przeanalizowania już wydanych pozwoleń zintegrowanych w kontekście zgodności ich treści z wymaganiami i zawartymi w konkluzjch oraz podjęcie działań formalnoprawnych celem dostosowania treści tych pozwoleń do nowych wymagań środowiskowoprawnych. Po trzecie, jest to obowiązek kontroli oraz ewentualnego zastosowania prawnych środków zmierzających do wyegzekwowania dostosowania przez przedsiębiorców instalacji do wymagań konkluzji dotyczących NDT dla obiektów energetycznych (kontrola i wymuszanie wykonania przez prowadzących instalacje obowiązków formalnoprawnych oraz faktycznych). Podobnie obowiązki podmiotów prowadzących określone instalacje wynikające z opublikowania konkluzji dotyczących NDT dla obiektów energetycznych możemy zakwalifikować do trzech grup: a) udzielanie organom administracji informacji koniecznych do przeprowadzenia należytej analizy wydanych pozwoleń zintegrowanych; b) podjęcie działań formalnoprawnych związanych z dostosowaniem treści posiadanego pozwolenia zintegrowanego do wymagań konkluzji dotyczacych NDT dla obiektów energetycznych; c) podjęcie i zakończenie w ciagu czterech lat (od dnia publikacji konkluzji) działań faktycznych zmierzających do dostosowania instalacji do wymagań konkluzji.

Odnosząc się do relacji dokumentów referencyjnych NDT do opracowanych na ich podstawie konkluzji dotyczących NDT, wskazać trzeba na odmienny charakter prawny tych dokumentów. Dokumenty referencyjne NDT nie maja charakteru prawnie wiążącego ${ }^{20}$, zawieraja jedynie rekomendacje (zalecenia) w zakresie kształtowania treści pozwoleń zintegrowanych w okresie, w którym konkluzje dotyczace NDT nie została jeszcze przyjęte i opublikowane. Do dnia opublikowania konkluzji dotyczących NDT dla obiektów energetycznych organ administracji, wydając pozwolenie, związany był ogólnymi (regulowanymi w dyrektywie 2010/75/UE i przepisach krajowych ją implementujacych) wymaganiami w zakresie poziomów dopuszczalnych emisji oraz zakresu i sposobu monitorowania ich wielkości ${ }^{21}$. Właściwy organ administracji powinien był jednak rozważyć modyfikację tych ogólnych wymagań, jeżeli dokumenty

\footnotetext{
20 Szerzej Lee (2014): 119.

${ }^{21}$ Górski (2014a): 632.
} 
referencyjne NDT wskazywały na dalej idące wymagania ${ }^{22}$. Rozstrzygnięcie organu administracji $\mathrm{w}$ zakresie stopnia uwzględnienia zaleceń zawartych w dokumentach referencyjnych NDT (ocena wzajemnych relacji pomiędzy wymaganiami ogólnymi a tymi ujętymi w dokumentach referencyjnych NDT) „mogło być kwestionowane przez prowadzącego instalację tylko w drodze odwołania od decyzji” ${ }^{23} \mathrm{w}$ przedmiocie pozwolenia zintegrowanego. Taki charakter dokumentu referencyjnego nie gwarantował stosowania wymagań NDT.

\section{ZMIANA WYMAGAŃ ŚRODOWISKOWOPRAWNYCH FUNKCJONOWANIA INSTALACJI OBJĘTYCH KONKLUZJAMI}

W kwestii relacji pomiędzy postanowieniami konkluzji dotyczących NDT a postanowieniami zawartymi w treści dyrektywy 2010/75/UE, a także implementującymi ją przepisami prawa krajowego należy stwierdzić, że postanowienia zawarte $\mathrm{w}$ konkluzjach stanowią swego rodzaju lex specialis $\mathrm{w}$ stosunku do regulacji dyrektywy 2010/75/UE oraz prawa krajowego. Konkluzje dotyczące NDT posiadaja pierwszeństwo obowiązywania i stosowania w stosunku do przepisów dyrektywy 2010/75/UE oraz regulacji krajowych, które z kolei mają zastosowanie jedynie do kwestii nieuregulowanych w konkluzjach. Opublikowanie konkluzji dotyczących NDT co do zasady wyłącza wymagania ogólne w zakresie regulowanym w konkluzjach, wyłącza też uznaniowość organu administracji odnośnie do uwzględnienia wymagań zawartych w dokumentach referencyjnych NDT. Jedynie w przypadku, gdy działalność lub rodzaj procesu prowadzonego w obrębie instalacji nie sa objęte żadnymi konkluzjami dotyczącymi NDT lub konkluzje te nie uwzględniają wszystkich możliwych skutków tych działalności lub procesów dla środowiska właściwy - organ określa warunki pozwolenia zintegrowanego na podstawie NDT określonych dla danej działalności lub procesu w dyrektywie 2010/75/UE (rozważając kryteria zawarte w załączniku III) ${ }^{24}$, które stanowia jedynie minimalny standard prawnośrodowiskowy w tym zakresie (art. 14 ust. 6 dyrektywy 2010/75/UE). Dyrektywa 2010/75/UE reguluje standardy emisyjne odnośnie do dwutlenku siarki, tlenku azotu oraz pyłów. Konkluzje dotyczące NDT dla obiektów energetycznych, po pierwsze, ograniczają limity emisji dwutlenku siarki, tlenku azotu oraz pyłów (w porównaniu z dyrektywą 2010/75/UE); po drugie, rozszerzają listę zanieczyszczeń także o rtęć, chlorowodór, amoniak i fluorowodór; po trzecie, wprowadzaja wymagania odnośnie do efektywności energetycznej; po czwarte, wprowadzają bardziej rygorystyczne obowiązki dotyczące monitoringu.

Należy zaznaczyć, że zakres wymagań środowiskowoprawnych uregulowanych w treści konkluzji dotyczących NDT dla obiektów energetycznych jest

\footnotetext{
22 Lange (2008): 104.

${ }^{23}$ Górski (2014a): 643.

${ }^{24}$ Oosterhuis, Peeterson (2014): 99.
} 
różny w zależności od tego, czy dana instalacja kwalifikowana jest jako obiekt „nowy”, czy „istniejaccy”. Kryterium tej kwalifikacji jest data publikacji konkluzji. Zgodnie z treścią konkluzji dotyczących NDT dla obiektów energetycznych „obiektem nowym” jest „obiekt energetycznego spalania, który po raz pierwszy uzyskał pozwolenie w instalacji po opublikowaniu konkluzji NDT lub całkowicie zastapiony na istniejących fundamentach po opublikowaniu konkluzji NDT”, z kolei „obiektem istniejacym” jest „obiekt energetycznego spalania, który nie jest nowym obiektem".

Należy rozważyć, jak kwalifikowana będzie instalacja w sytuacji, w której pozwolenie zintegrowane na jej funkcjonowanie zostało wydane przed dniem opublikowania konkluzji, ale walor ostateczności decyzja ta uzyskała 17 sierpnia 2017 r. lub później. W orzecznictwie przyjęte zostało stanowisko, że właściwy organ, wydając decyzję administracyjna, zobowiązany jest do wydania rozstrzygnięcia na podstawie stanu faktycznego i prawnego istniejącego w chwili wydania decyzji. Naczelny Sąd Administracyjny w wyroku z 4 października 2000 r. ${ }^{25}$ stwierdził, że „należy wskazać [...] na potrzebę stosowania norm prawa materialnego obowiązującego w dniu wydania decyzji”. Podobnie w literaturze przedmiotu podnosi się, że organ administracji ocenia stan prawny sprawy „według chwili wydania decyzji administracyjnej” ${ }^{26}$. Wobec powyższego należy wnioskować, że przy kwalifikacji instalacji jako obiektu nowego lub istniejącego „należy brać pod uwagę datę wydania po raz pierwszy pozwolenia zintegrowanego przez organ pierwszej instancji”27. Co do zasady fakt uzyskania waloru ostateczności przez tę decyzję 17 sierpnia 2017 r. lub później nie ma znaczenia dla tej kwalifikacji. Przy czym należy mieć na uwadze sytuację zaskarżenia decyzji organu pierwszej instancji i wydania przez organ drugiej instancji decyzji kasatoryjnej. Zgodnie z wyrokiem Naczelnego Sądu Administracyjnego z 21 grudnia 1999 r.: ,jeśli przepisy prawa materialnego ulegna zmianie $\mathrm{w}$ czasie między wydaniem decyzji pierwszej instancji a rozpatrzeniem odwołania, organ odwoławczy - zachowując tożsamość sprawy - obowiązany jest uwzględnić nowy stan prawny, chyba że z nowych przepisów wynika coś innego. Organ ten orzeka bowiem w sposób merytoryczny"28.

Co do zasady czasowy zakres, od którego określone instalacje podlegaja wymaganiom uregulowanym w konkluzjach dotyczących NDT dla obiektów energetycznych, rozpoczyna się wraz z upływem czterech lat od publikacji konkluzji (17 sierpnia 2021 r.). Prawodawca unijny przewidział jednak dwa wyjątki od tej zasady. Po pierwsze, na mocy samej decyzji w przedmiocie konkluzji dotyczaccych NDT dla obiektów energetycznych wymaganiom konkluzji nie podlegaja instalacje korzystajace $\mathrm{z}$ derogacji przyznanej im na podstawie art. 33 i 35 dyrektywy 2010/75/UE w okresie jej trwania. Po drugie, właściwy organ na wniosek prowadzącego instalacje może udzielić czasowego odstępstwa od wymagań konkluzji dotyczących NDT dla obiektów energetycznych.

25 NSA 283/00, Lex nr 50110.

${ }^{26}$ Jaśkowska, Wróbel (2012).

27 Zob. <http://www.ekoportal.gov.pl/fileadmin/Ekoportal/Pozwolenia_zintegrowane/wyjasnienia /interpretacja_Konkluzje_BAT_dla_LCP_1.pdf> [dostęp: 31.12.2018].

${ }^{28}$ Wyrok NSA z 21 grudnia 1999 r., IV SA 2079/9. 
Odstępstwo to dotyczyć może jedynie zakresu poziomu dopuszczalnych emisji. Możliwość uzyskania odstępstwa wyłączona jest odnośnie do zakresu i sposobu monitorowania emisji. Co więcej, właściwy organ może ustalić w treści pozwolenia zintegrowanego dla danej instalacji mniej restrykcyjne dopuszczalne wielkości emisji tylko wtedy, gdy łącznie spełnione zostaną dwa warunki: a) osiągnięcie poziomów emisji powiązanych z NDT opisanymi w konkluzjach prowadziłoby do nieproporcjonalnie wysokich kosztów w stosunku do korzyści dla środowiska (dowiedzenie, że koszty dostosowania do wymogów konkluzji dotyczacych NDT są nieproporcjonalnie wysokie w stosunku do korzyści dla środowiska), ze względu na: położenie geograficzne danej instalacji lub lokalne warunki środowiskowe lub charakterystykę techniczną danej instalacji; b) nie zostały przekroczone standardy emisyjne, o ile mają one zastosowanie (art. 204 ust. 3 p.o.ś.) ${ }^{29}$. Uznając możliwość zaistnienie wskazanych wyżej przesłanek, organ ustala poziom dopuszczalnej emisji według zasad ogólnych, odwołując się do standardów emisyjnych. Zasadność udzielenia odstępstwa podlega kontroli społecznej $\mathrm{w}$ ramach przeprowadzonego postępowania z udziałem społeczeństwa. O zastosowaniu odstępstwa państwa członkowskie informują też Komisję Europejską. Ponadto organ administracji zobowiązany jest analizować zasadność zastosowania odstępstwa ponownie przy każdej kolejnej aktualizacji pozwolenia zintegrowanego. Istotna kwestia jest również to, że złożenie wniosku o udzielenie odstępstwa nie wstrzymuje biegu czteroletniego okresu na dostosowanie instalacji do wymagań konkluzji dotyczących NDT. Wyjątkowy charakter przedmiotowego odstępstwa (co podkreślane jest $\mathrm{w}$ literaturze przedmiotu ${ }^{30}$ ) oraz niesuspensywny charakter tego postępowania rodzą ryzyko dla prowadzącego instalację, że zostanie na niego nałożona sankcja prawna z tytułu nieterminowanego dostosowania instalacji do wymagań konkluzji, w szczególności gdy ten przedsiębiorca jednocześnie z zainicjowaniem postępowania w sprawie udzielenia odstępstwa nie podejmie działań dostosowawczych (faktycznych).

\section{OBOWIĄZKI FORMALNOPRAWNE WYNIKAJĄCE Z OPUBLIKOWANIA KONKLUZJI}

Właściwe organy powinny regularnie poddawać ponownemu rozpatrzeniu warunki udzielonych pozwoleń zintegrowanych oraz w stosownych przypadkach dokonywać ich aktualizacji, w szczególności gdy przyjmuje się nowe lub uaktualnione konkluzje dotyczące NDT (motyw nr 21 dyrektyw 2010/75/UE). Doprecyzowując ten obowiązek, przepisy krajowe nakładają na właściwy organ niezwłocznie (nie później niż 6 miesięcy) po publikacji konkluzji odnoszących się do głównej działalności danej instalacji wymóg analizy treści warunków

${ }^{29}$ Ministerstwo Środowiska 22 sierpnia 2017 r. opublikowało podręcznik dotyczący zasad udzielania odstępstw od granicznych wielkości emisyjnych zawartych w konkluzjach NDT dla obiektów energetycznych.

${ }^{30}$ Oosterhuis, Peeterson (2014): 98. 
pozwolenia zintegrowanego (art. 215 ust. 1 p.o.ś.). Właściwy organ o rozpoczęciu tej analizy powinien powiadomić prowadzącego instalacje (art. 215 ust. 2 p.o.ś.). Celem postępowania wszczętego na podstawie art. 215 p.o.ś. jest zbadanie przez właściwy organ, czy pozwolenie zintegrowane w aktualnej wersji jest zgodne z wymaganiami prawa unijnego, oraz ewentualne wskazanie, które konkretnie jego elementy wymagają zmiany ${ }^{31}$. Mając na względzie konieczność przeprowadzenia tej analizy w jak najbardziej należyty sposób organ może zażądać od prowadzącego instalację przedłożenia niezbędnych informacji, w szczególności wyników monitorowania procesów technologicznych (art. 215 ust. 3 p.o.ś.). Uznanie przez organ administracji konieczności zmiany przeanalizowanego pozwolenia rodzi po stronie organu „dwa obowiązki przekazania prowadzącemu instalację informacji o konieczności dostosowania instalacji oraz wezwania go do wystapienia z wnioskiem o zmianę pozwolenia $\mathrm{w}$ terminie roku od dnia doręczenia wezwania, określając zakres tego wniosku"32 (art. 215 ust. 4 p.o.ś.). Wymienione obowiązki organu pociagają za soba odpowiednie obowiązki prowadzącego instalacje, w szczególności udzielenie informacji i złożenie wniosku o zmianę warunków pozwolenia.

Niestety, ani przepisy dyrektywy 2010/75/UE, ani przepisy prawa krajowego nie precyzuja charakteru prawnego postępowania prowadzonego przez organ administracji zmierzającego do oceny zgodności warunków pozwolenia zintegrowanego z wymaganiami konkluzji dotyczącymi NDT, a także jaką formę powinny przybrać konkluzje organu administracji. W literaturze przedmiotu pojawił się pogląd, że wyniki przeprowadzonej przez organ administracji oceny powinny zostać zakwalifikowane jako „akt lub czynność nie majacca charakteru decyzji lub postanowienia, mające charakter publicznoprawny, skierowane do indywidualnego podmiotu i dotyczące jego uprawnień bądź obowiązków wynikających z przepisów prawa" (art. 3 § 2 pkt 4 ustawy z 30 sierpnia 2002 r. - Prawo o postępowaniu przed sądami administracyjnymi) ${ }^{33}$. W związku z tym mogą być zaskarżone w drodze wniesienia skargi administracyjnej. Wskazuje się też, że poinformowanie prowadzącego instalację o rozpoczęciu analizy stanowi wszczęcie postępowania administracyjnego w znaczeniu Kodeksu postępowania administracyjnego ${ }^{34}$ (realizację obowiązku zawiadomienia stron o wszczęciu postępowania zawartego w art. $61 \S 4$ k.p.a. $)^{35}$. Natomiast, zdaniem niektórych przedstawicieli doktryny, wezwanie prowadzącego instalację do wystapienia z wnioskiem o zmianę pozwolenia zintegrowanego stanowić powinno decyzję administracyjną w znaczeniu k.p.a. (spełniać powinno wymagania zawarte w art. 107 k.p.a.), stanowi bowiem „przejaw klasycznego władczego działania organu administracji, które bezpośrednio

${ }^{31}$ Górski (2014a): 654.

32 Górski (2014a): 654.

${ }^{33}$ T.jedn.: Dz. U. 2018, poz. 1302 ze zm. (dalej jako: p.p.s.a.). Gruszecki (2016).

${ }^{34}$ Ustawa z 14 czerwca 1960 r. - Kodeks postępowania administracyjnego, t.jedn.: Dz. U. 2018, poz. 2096 ze zm. (dalej k.p.a.).

35 Źródło: <http://www.srodowisko.abc.com.pl/czytaj/-/artykul/jaka-forme-powinno-miec-zadanie -przedlozenia-informacji-dotyczacych-analizy-pozwolenia-zintegrowanego-w-zwiazku-z-publikacja-konkluzji-bat> [dostęp: 31.12.2018]. 
wywołuje skutki prawne dla ich adresatów" (spełnione są wszystkie przesłanki wynikające z art. 104 k.p.a. $)^{36}$.

Przypomnieć należy, że postępowanie administracyjne to postępowanie $\mathrm{w}$ indywidualnych sprawach rozstrzyganych $\mathrm{w}$ drodze decyzji administracyjnych albo załatwianych milcząco (art. 1 pkt 1 k.p.a.). Decyzja administracyjna jest władczym i jednostronnym oświadczeniem woli organu administracji rozstrzygajacym co do istoty o uprawnieniach lub obowiazkach podmiotu niepowiązanego organizacyjnie $\mathrm{z}$ organem wydającym dany akt lub podejmującym daną czynność.

W orzecznictwie wskazuje się, że dla stwierdzenia, że organ administracji jest uprawniony do wydania decyzji administracyjnej, musi wystapić wyraźne i wystarczające określenie w przepisie prawa materialnego jego kompetencji w formie czasownikowej „zezwala”, „przydziela” lub „stwierdza” ${ }^{7}$. Odnosząc się jednak wobec wyżej zasygnalizowanych poglądów, a w szczególności do formy wezwania prowadzącego instalację do wystapienia $\mathrm{z}$ wnioskiem o zmianę pozwolenia, wskazać trzeba, że można mieć wattpliwości, czy rzeczywiście mamy w tym przypadku do czynienia z „władczym” oświadczeniem woli, czyli takim, które wywołuje bezpośredni skutek w postaci rozstrzygnięcia o prawach lub obowiązkach podmiotu prowadzącego instalację (co w konsekwencji może podważyć twierdzenie, że wezwanie ma formę decyzji administracyjnej). Co prawda niewystapienie przez prowadzącego instalację z wnioskiem o zmianę pozwolenia zintegrowanego $\mathrm{w}$ terminie roku od dnia doręczenia tego wezwania może skutkować wydaniem decyzji zgodnie z art. 195 ust. 1 pkt 5 p.o.ś. w przedmiocie cofnięcia lub ograniczenia bez odszkodowania pozwolenia zintegrowanego, a w konsekwencji pozbawieniem możliwości prowadzenia danej działalności gospodarczej. Jednakże aby ten skutek wystapił, organ musi wszcząć osobne postępowanie w przedmiocie cofnięcia lub ograniczenia bez odszkodowania pozwolenia zintegrowanego, które zakończy się decyzją administracyjna, a na tę decyzję przysługiwać będzie odwołanie. Samo wezwanie nie powoduje „automatycznie” pozbawienia prowadzącego instalację pozwolenia zintegrowanego. Dopiero decyzja administracyjna w przedmiocie cofnięcia lub ograniczenia pozwolenia zintegrowanego bez odszkodowania wpływać będzie bezpośrednio na sytuację prawną prowadzącego instalację. Przedmiotem (treścia) wezwanie jest jedynie wskazanie zakresu czynności, które prowadzący instalację powinien podjąć, aby ta instalacja funkcjonowała zgodnie z wymaganiami konkluzji dotyczącymi NDT ${ }^{38}$.

Z powodu „nierozstrzygania w sposób wiążący o uprawnieniach podmiotu prowadzącego instalację”, „braku ścisłego i bezpośredniego związku między wezwaniem a pozbawieniem przedsiębiorcy uprawnień do prowadzenia instalacji” ${ }^{39}$ wydaje się, że można też podważyć pogląd, że wyniki przeprowadzonej przez organ administracji oceny powinny zostać zakwalifikowane jako akt lub

\footnotetext{
${ }^{36}$ Gruszecki (2016).

37 Uchwała składu 5 sędziów NSA z 9 października 2000 r., OPK 15/00.

38 Postanowienie WSA w Szczecinie z 18 października 2017 r., II SA/Sz 1041/17.

${ }^{39}$ Uchwała składu 7 sędziów NSA z 3 września 2013 r., I OPS 2/2013.
} 
czynność określone w art. $3 \S 2$ pkt 4 p.p.s.a. i mogą być przez to zaskarżone $\mathrm{w}$ drodze skargi administracyjnej.

Postępowanie w przedmiocie oceny zgodności warunków pozwolenia zintegrowanego z wymaganiami konkluzji dotyczącymi NDT należałoby raczej uznać nie za postępowanie administracyjne, ale za wykonywanie przez właściwy organ uprawnień kontrolnych w zakresie przestrzegania i stosowania przepisów o ochronie środowiska w znaczeniu art. 379 ust. 1 p.o.ś. Można się zastanowić nad tym, czy przepis art. 215 ust. 2 pkt 2 p.o.ś. (zażądanie od prowadzacego instalację przedłożenia informacji) nie będzie wyłączał przepisu art. 379 ust. 3 p.o.ś. (uprawnienia kontrolującego). Przekazanie prowadzacemu instalację informacji o konieczności jej dostosowania można traktować jako wnioski z kontroli wskazujące na potrzebę podjęcia pewnych czynności, a wezwania prowadzącego instalację do wystapienia z wnioskiem o zmianę pozwolenia zintegrowanego raczej powinno się kwalifikować jako konstytutywną czynność materialno-techniczna ${ }^{40}$. W tej sytuacji wydaje się, że prowadzacy instalację dopiero w odwołaniu od decyzji w przedmiocie cofnięcia lub ograniczenia bez odszkodowania pozwolenia zintegrowanego będzie mógł zakwestionować wyniki przeprowadzonej przez organ administracji oceny zgodności warunków pozwolenia zintegrowanego z wymaganiami konkluzji dotyczacymi NDT oraz zasadność wezwania go do złożenia wniosku o zmianę pozwolenia.

\section{KONSEKWENCJE NIEZLOŻENIA WNIOSKU O ZMIANE POZWOLENIA ORAZ NIEDOSTOSOWANIA INSTALACJI DO WYMOGÓW KONKLUZJI}

W przypadku niepodjęcia przez prowadzącego instalację odpowiednich działań w zakresie złożenia wniosku o zmianę pozwolenia zintegrowanego na wezwanie właściwego organu, organ nie może zmienić pozwolenia z urzędu. Postępowanie w przedmiocie wydania pozwolenia na korzystanie ze środowiska wszczynane jest wyłącznie na wniosek (art. 184 ust. 1 p.o.ś.). Dostępnym środkiem prawnym, jaki może zostać podjęty przez organ, jest wszczęcie na podstawie art. 195 ust. 1 pkt 5 p.o.ś. postępowania w przedmiocie cofnięcia lub ograniczenia bez odszkodowania pozwolenia zintegrowanego i wydania odpowiedniej decyzji, a w konsekwencji pozbawienie przedsiębiorcy możliwości prowadzenia danej działalności gospodarczej (ewentualnie ograniczenie zakresu).

Podmiot prowadzący instalacje będzie zobowiązany do dostosowania instalacji do nowych wymagań określonych w konkluzjach dotyczących NDT dla obiektów energetycznych w terminie określonym w wydanej przez organ decyzji zmieniającej pozwolenie zintegrowanego, który nie powinno zostać określony później niż na dzień, w którym upłynie okres czterech lat od dnia opu-

${ }^{40}$ Górski (2014a): 654. 
blikowania decyzji w przedmiocie konkluzji dotyczących NDT (art. 215 ust. 5 p.o.ś.). Jeżeli wymagania zawarte w konkluzjach dotyczących NDT nie zostałyby wdrożone w terminie określonym w nowo wydanej decyzji zmieniajacej warunki pozwolenie, organ również ma możliwość cofnięcia lub ograniczenia bez odszkodowania tego pozwolenia na podstawie art. 195 ust. 1 pkt 1 p.o.ś. Należy podkreślić, że przepis art. 195 ust. 1 p.o.ś. przewiduje kompetencję właściwego organu ochrony środowiska o charakterze fakultatywnym ${ }^{41}$. Organ ma możliwość, ale nie obowiązek cofnięcia lub ograniczenia pozwolenia $\mathrm{w}$ przypadkach wymienionych w tym przepisie. Organ dokonuje oceny potrzeby wydania takiej decyzji. Uznanie przez organ konieczności zastosowania sankcji w postaci cofnięcia lub ograniczenia pozwolenia powinno wynikać z „przekonania, że inny sposób doprowadzenia do przestrzegania prawa nie jest możliwy" ${ }^{42}$. Co więcej, w przypadku przesłanki określonej w art. 195 ust. 1 pkt 1 p.o.ś. przed wydaniem decyzji w przedmiocie cofnięcia lub ograniczenia pozwolenia organ wzywa prowadzącego instalację do usunięcia naruszeń w oznaczonym terminie. Organ, wyznaczając ten termin, będzie działał uznaniowo, powinien jednak brać pod uwagę z jednej strony „konieczność doprowadzenia do przestrzegania prawa w możliwie najkrótszym czasie, z drugiej strony zaś, ocenić faktyczną możliwość zrealizowania przez zobowiązanego nakładanych na niego obowiązków” ${ }^{43}$.

Należy też dodać, że w razie wprowadzania przez podmiot korzystający ze środowiska substancji lub energii do środowiska z naruszeniem warunków pozwolenia wojewódzki inspektor ochrony środowiska może wstrzymać, w drodze decyzji, użytkowanie instalacji (art. 367 ust. 1 p.o.ś). Za przekroczenie określonych w pozwoleniu ilości lub rodzaju gazów lub pyłów wprowadzanych do powietrza wojewódzki inspektor ochrony środowiska wymierza administracyjną karę pieniężną (art. 298 ust. 1 p.o.ś.).

\section{WNIOSKI}

Wprowadzony do unijnego porządku prawnego (w konsekwencji do krajowych porządków prawnych) instrument konkluzji dotyczących NDT jest instrumentem systematycznie obejmującym kolejne obszary działalności gospodarczej (coraz to nowe rodzaje instalacji), poszerzajac obszar zintegrowanego podejścia państw członkowskich do problemów zanieczyszczenia środowiska. W konsekwencji instrument ten odgrywa coraz większe znaczenie w ochronie środowiska, w szczególności w kontekście coraz szybciej rozwijających się nowych technik i technologii mogacych wypływać na ograniczenie zanieczyszczeń środowiska. Takimi konkluzjami są też opublikowane konkluzje dotyczące NDT dla obiektów energetycznych.

\footnotetext{
41 Górski (2014b): 613.

${ }^{42}$ Górski (2014b): 612.

${ }^{43}$ Górski (2014b): 615.
} 
Konkluzje NDT dla obiektów energetycznych skutkować będą zmianą wymagań środowiskowoprawnych dla objętych nimi instalacji (ograniczą obecne limity emisji dwutlenku siarki, tlenku azotu oraz pyłów; rozszerzą listę zanieczyszczeń także o rtęć, chlorowodór, amoniak i fluorowodór; wprowadzą wymagania odnośnie do efektywności energetycznej; wprowadzą bardziej rygorystyczne obowiązki dotyczące monitoringu). Są to zmiany daleko idące, wymagają też podjęcia szeregu działań - zarówno formalnoprawnych, jak i faktycznych przez podmioty prowadzace te instalacje lub przez organy administracji.

Nieterminowe lub nienależyte zrealizowanie tych obowiązków, przez organy administracji lub podmioty prowadzace instalacje, może skutkować odpowiedzialnością państwa członkowskiego UE z tytułu nienależytego stosowania prawa unijnego, a przede wszystkim prowadzącego instalację, przejawiająca się głównie cofnięciem lub ograniczeniem bez odszkodowania pozwolenia zintegrowanego, a w konsekwencji - pozbawieniem możliwości prowadzenia danej działalności gospodarczej. Mając na względzie rolę sektora energetycznego dla funkcjonowania całej gospodarki i polityki państwa, w szczególności „wyłączenie" dużych instalacji działajaccych w sektorze energetyczny z powodu braku zgodności z wymaganiami konkluzji dotyczącymi NDT dla obiektów energetycznych, może mieć istotny wpływ na różne dziedzin gospodarki. Jasność, właściwa interpretacja obowiązów ciążących na organach i podmiotach prowadzacych instalacje, w tym procedur, które muszą zostać przeprowadzone, charakteru przysługujących środków prawnych, możliwych odstępstw, są konieczne, aby „obie strony” należycie wykorzystały czteroletni okres na dostosowanie prowadzonych instalacji do nowych wymagań prawnośrodowiskowych i zakończyły ten proces dostosowań zarówno formalnoprawnych, jak i faktycznych terminowo i należycie.

Kamila Sobieraj

Katolicki Uniwersytet Lubelski Jana Pawła II

sobieraj@kul.lublin.pl

https://orcid.org/0000-0001-6432-4977

Bar, M. (2012). Dyrektywa 2010/75/UE, [w:] J. Jendrośka (red.), Leksykon prawa ochrony środowiska. Warszawa: 38.

Brzeziński, P. (2010). Unijny obowiązek odmowy zastosowania przez sąd krajowy ustawy niezgodnej z dyrektywą Unii Europejskiej. Warszawa: 104-176.

Ciechanowicz-McLean, J. (2015). Prawo ochrony i zarządzania środowiskiem. Warszawa.

Ciechanowicz-McLean, J., Nyka, M. (2011). Nowe instrumenty administracyjnoprawne w ochronie środowiska, [w:] M. Rudnicki, A. Haładyj, K. Sobieraj (red.), Dekada harmonizacji w prawie ochrony środowiska. Lublin: 173-202.

Erechemla A. (2010). Prawo ochrony środowiska Unii Europejskiej, [w:] P. Korzeniowski (red.), Prawa i obowiązki przedsiębiorców w ochronie środowiska. Zarys encyklopedyczny. Warszawa: $36-64$.

Górski, M. (2014a). Rozdział 4. Pozwolenia zintegrowane Dział IV Pozwolenia na wprowadzanie do środowiska substancji lub energii Tytuł III Przeciwdziałanie zanieczyszczeniom, [w:] M. Górski, M. Pchałek, W. Radecki, I. Jerzmański, M. Bar, S. Urban, J. Jendrośka, Prawo ochrony środowiska. Komentarz. Warszawa: 623-667.

Górski, M. (2014b). Rozdział 3. Wygaśnięcie, cofnięcie i ograniczenie pozwolenia Dział IV Pozwolenia na wprowadzanie do środowiska substancji lub energii Tytuł III Przeciwdziałanie 
zanieczyszczeniom, [w:] M. Górski, M. Pchałek, W. Radecki, I. Jerzmański, M. Bar, S. Urban, J. Jendrośka, Prawo ochrony środowiska. Komentarz. Warszawa: 603-623.

Górski M. (2018). Ochrona jakości środowiska i prawo emisyjne, [w:] M. Górski (red.), Prawo ochrony środowiska. Warszawa: 255.

Gruszecki, K. (2016). Komentarz do art. 215 ustawy - Prawo ochrony środowiska. Lex/el.

Hedemann-Robinson, M. (2015). Enforcement of European Union Environmental Law: Legal Issues and Challenges. London-New York.

Oosterhuis F., Peeterson, M. (2014). Limits to integration in pollution prevention and control, [w:] M. Peeters, R. Uylenburg (eds.), EU Environmental Legislation: Legal Perspectives on Regulatory Strategies. Cheltenham-Northampton: 91-115.

Jaśkowska, M., Wróbel, A. (2012). Komentarz do ustawy z dnia 14 czerwca 1960 r. Kodeks postępowania administracyjnego. Lex/el.

Jendrośka, J., Bar, M., Górski, M. (2005). Zasady wydawania pozwoleń zintegrowanych. Praktyczny poradnik. Wrocław.

Kalisz, A. (2007). Wykładnia i stosowanie prawa wspólnotowego. Warszawa.

Kenig-Witkowska, M.M. (2011). Prawo środowiska Unii Europejskiej. Zagadnienia systemowe. Warszawa.

Kenowska, K.M. (2009). Najlepsze dostępne techniki, [w:] J. Ciechanowicz-McLean (red.), Leksykon ochrony środowiska. Warszawa: 134-137.

Korzeniowski, P. (2010). Zasady prawa ochrony środowiska. Łódź.

Kowalik-Bańczyk, K. (2012). Prawo do obrony w unijnych postępowaniach antymonopolowych: W kierunku unifikacji standardów proceduralnych w Unii Europejskiej. Warszawa.

Lee, M. (2014). EU Environmental Law, Governance and Decision-Making. Oxford.

Lange, B. (2008). Implementing EU Pollution Control: Law and Integration. Cambridge.

Langlet, D., Mahmoudi, S. (2016). EU Environmental Law and Policy, Oxford.

Muras, Z., Swora, M. (2016). Komentarz do art. 1, [w:] Z. Muras, M. Swora (red.), Prawo energetyczne. Tom 1: Komentarz do art. 1-11s. Lex/el.

Sobieraj, K. (2013). Prawo dostępu do energii jako warunek zrównoważonego rozwoju, [w:] Z. Garlicki, A. Gubrynowicz (red.), Międzynarodowe prawo ochrony środowiska XXI wieku. Warszawa: 257-266.

Szafrański, A. (2014). Prawo energetyczne. Wartości i instrumenty ich realizacji. Warszawa.

\section{THE LEGAL EFFECTS OF ADOPTING AND PUBLISHING CONCLUSIONS ON THE BEST AVAILABLE TECHNIQUES - CONSIDERING THE REQUIREMENTS FOR LARGE COMBUSTION PLANTS}

\section{Summary}

The publication of the conclusions of the best available techniques for large combustion plants has raised interest in this issue not only among administrative bodies and entities operating installations that are subject to these conclusions. The energy sector is a strategic area, from the point of view of the entire economy and state policy. The functioning of this sector (and the obligations imposed on it) has an impact on many other areas of the economy and social life. The purpose of this article is to analyze the consequences of the adoption - and primarily of the publication of - the conclusions (as of when they become binding) regarding the best available techniques for large combustion plants (that is, the changes in the environmental and legal situation of the installations covered by these conclusions, and as a consequence the obligations resulting from this fact for administrative bodies and entities running specific installations). This article also aims to outline the consequences of the delayed or improper implementation of the abovementioned obligations (both for the EU Member States and the operator conducting the installation).

Keywords: best available techniques; large combustion plants; air protection 